\title{
Heidegger and Husserl on the Technological-Scientific Worldview
}

\section{Corijn van Mazijk ${ }^{1}$ (1)}

Published online: 3 September 2019

(C) The Author(s) 2019

\begin{abstract}
This paper discusses the relation between the later Husserl and the later Heidegger regarding their criticisms of modern science and technology. It is suggested that the overlap between both accounts is more significant than is standardly acknowledged. The paper first explores Heidegger's ideas about the 'essences' of science and technology, how they allegedly determine the contemporary worldview, conceal our relation to being, and how Heidegger warrants his critical attitude toward this. It then discusses Husserl's philosophical-historical assessment of the 'idea' of modern science, which Husserl believed resulted in the decapitation of philosophical questioning. Although key differences in method, aims, and their proposed solution to the dominance of the technological-scientific worldview should not be overlooked, the paper suggests that core aspects of Heidegger's analyses can be traced back to Husserl.
\end{abstract}

Keywords Husserl · Heidegger · Technology · Science · Phenomenology · Lifeworld · Being

\section{Introduction}

In spite of the depth of the divergence of Heidegger's thinking from Husserl'swhich originated already during their collaborations in Freiburg ${ }^{1}$ and only deepened from thereon-there is a theme which unites near to all philosophical efforts of both

\footnotetext{
${ }^{1}$ Heidegger's thinking of the late 1910s and early 1920s could be qualified as 'essentially Husserlian' (Crowell 2013: 59). Heidegger's shift in focus to being took place in the course of the mid-1920s. The definitive nature of their break is perhaps most clearly expressed in the failed collaborative attempt on the Encyclopaedia Britannica article in 1927 (see Husserl 1997b), but also in Heidegger's publication of Being and Time.
}

Corijn van Mazijk

c.m.a.van.mazijk@rug.nl

https://corijnvanmazijk.com/

1 Faculty of Philosophy, Department of the History of Philosophy, University of Groningen, Oude Boteringestraat 52, 9712 GL Groningen, The Netherlands 
thinkers: their primal concern with the fate of western humanity. Husserl and Heidegger both operated in what is one of the most turbulent of all times western culture has had to endure. Moreover, both understood their own thinking directly in relation to an imminent crisis of the west. They both firmly believed humanity stood in need of a new spiritual orientation which the scientific developments of modernity had somehow been obstructing. Moreover, both felt that to provide such direction itself was to set on a kind of spiritual task which they had been called upon to take up.

Yet both thinkers took up this task in what prima facie appear to be very different ways. Husserl honestly considered that the transcendental phenomenology he had developed was the culmination of all the spiritual and philosophical efforts of human history (see Hua VI 13, 71). This progression of history for him was identical to the progression of reason. Transcendental phenomenology was to be the ultimate rational and therewith simultaneously the ultimate responsible philosophy. Evidently, the completion of such a trajectory ought itself to take a rational shape; it can only exist in complete transparency to itself, and thus must present itself in unambiguous terms and with demanding scientific rigor. It is from this towering viewpoint that Husserl claims to identify a threat to western society, seeks to trace its origins through modern history of science, and finally proposes a cure to it.

Heidegger understood his philosophical calling quite differently. It is often said that Heidegger was more sensitive to history, practice, and inter-subjectivity, and that the limits of reason within the bounds set by those factors was not understood by Husserl. It is hard, I think, to maintain such a view for anyone acquainted with the breadth and depth of Husserl's thought. But at the least it seems uncontroversial that Heidegger believed Husserl's project had to be rejected on grounds of it being an onto-theological hubris beyond the reach of mortal beings. This is hardly a signal of modesty on Heidegger's behalf, however, who in turn claimed insight into the peculiar form of understanding shaping his time unavailable to most others. ${ }^{2}$ This form of understanding is what he called the 'essence' of technology (Wesen der Technik), ${ }^{3}$ in turn closely related to the so-called 'essence' of modern science (Wesen der modernen Wissenschaft). ${ }^{4}$ For Heidegger, the threat posed by them does not lie in obfuscating the one true path of reason, but in concealing our relationship to being.

In spite of the abundance of literature on the relation between various aspects of their thinking, Heidegger's later critique of technology and science ${ }^{5}$ is still rarely studied with regard to its relation to Husserl's critique of modern science and

\footnotetext{
${ }^{2}$ In the 1975 NESKE television interview Heidegger sees himself and his understanding of the task of thinking as akin to those 'five or six' scientists who truly understand the 'physical laws' governing the workings of a radio or television.

3 In Die Frage nach der Technik (1953), referred to with abbreviations 'FT'.

4 In Wissenschaft und Besinnung (1953), referred to with abbreviations 'WuB'. Two other texts of this volume (GA 7) Überwindung der Metaphysik and Wer ist Nietzsches Zarathustra are referred to with abbreviations 'ÜdM' and 'WNZ'.

5 An early, albeit more implicit, critique of science can also be found in the earlier Sein und Zeit (1927), see Pleger (1989) for an able discussion.
} 
technological thinking. Although no sufficient reasons, this could be partially due to the lack of strong evidence that Heidegger studied Husserl's Krisis der europäischen Wissenschaften (1936) ${ }^{6}$ or simply to the notorious difficulty of Husserl's work generally. It may also have to do with Heidegger's so-called Kehre, ${ }^{7}$ which is generally seen as weakening ties to phenomenology — and thus also, it may be assumed, to Husserl's critique of modern science. It would be contentious, however, to qualify Husserl's historical analyses in his final work as strictly phenomenological—which means this too cannot straightforwardly dispense of the need to explore the convergence of their respective critiques of the technological-scientific worldview.

This paper seeks to explore the depth of that convergence as well as to highlight the essentially different philosophical viewpoints from which it takes place. In contra-chronological order, section two first deals with Heidegger's critique of technology and science in his writings after the Kehre. After that, section three traces some of Heidegger's ideas in Husserl's interpretation developed just over 15 years earlier. In the final part, I conclude that, irrespective of the historical question whether Heidegger studied Husserl's final work in detail, many core aspects of Heidegger's critique can be traced back to Husserl.

\section{Heidegger on the Technological-Scientific Worldview}

Few scholars would say Heidegger's later writings on technology are an easy read. This is particularly due to the way they are tied into his elusive philosophy of being. Indeed, the 'essence' of technology has 'everything' to do with being (FT 16). It can therefore be useful to start from a distinction made much earlier by Heidegger called the ontological difference (ontologische Differenz). ${ }^{8}$ As Nicholson (1985) put it some 30 years ago, the ontological difference is between 'on one side, all that exists, on the other, the very existence of what exists' (Nicholson 1985: 357). In other words, it is the difference between what is and the being of what is; so between beings and their being.

At first sight, this may not seem to get us very far. The distinction between being and beings - traditionally understood within the dichotomy of essences or substances as abstract property-bearers and their predicables-is obviously an old one, and making it by no means solves the problem of how exactly to account for being. Traditional western philosophy has understood being both as property - a special kind of property (Aquinas, among others) or a property of concepts or propositional constructs (Frege and Russell, respectively) — and not as a property (most notably Locke and Hume; the former regarding being as substance, the latter rejecting

\footnotetext{
${ }^{6}$ Full title: Krisis der europäischen Wissenschaften und die transzendentale Phänomenologie: Eine Einleitung in die phänomenologische Philosophie. The work is usually considered unfinished; see Bossert (1974) for a discussion. According to Cumming, there is no evidence Heidegger studied the work (Cumming 2001: 145).

7 There is no consensus on when the Kehre took place. It is usually located in the 1930s, after the publication of Being and Time but before the work on technology.

8 The term first appears in the 1927 summer lecture Die Grundprobleme der Phänomenologie.
} 
sub-stances 'standing under' sensible properties). As is well known, Heidegger believed the general approach underlying all these views to be false. For him, being can be thought of neither as sub-stance accommodating properties nor as a property itself. It must, therefore, be qualified in a wholly different way, as was Heidegger's principal concern throughout his career.

Although a somewhat blunt over-generalization, it can be helpful to distinguish two general ways in which Heidegger approached the issue of being. First, we can think of the earlier Heidegger (of Sein und Zeit) as interested particularly in what enables us (as 'Dasein') to relate to being. Simpler put: what sort of conditions (Existenzialen) need be in place in order for Dasein to be able to ask the question of being in the first place (SZ 11-15)? ${ }^{9}$ This first approach, then, rather than taking the problem head on, circles it by asking for the conditions presupposed by the very question. Asking for the conditions for asking about being (a capacity most of the other animals presumably lack) allowed Heidegger to embark on a relatively systematic 'transcendental' (concerning conditions of possibility) task, as we find in Being and Time.

Second, the Heidegger after the Kehre can be thought of as occupied primarily with our contemporary lack of concern for being. The issue to be understood here is: how come we do not ask about being? Or put differently: why did being drift so far out of sight? And how might we ever retrieve it again more fully? Arguably, this is a more elusive concern than the earlier one, and Heidegger's approach to it did not involve breaking it down into a network of interrelated conditions of possibility. To some extent, this absence of a quasi-analytic pursuit of various conditions of possibility explains the (yet more) cryptic flavor of the later writings.

To be sure, twentieth century philosophy did ask the question of being. It would be absurd to claim that the whole issue of being escaped notice of philosophers at any epoch of traditional philosophy from Thales up to now. But Heidegger, as everybody knows, believed they all asked the question in the wrong way. The right way of thinking about being, Heidegger thought, has drifted out of sight. Looking for the source or cause of this is precisely what brought the later Heidegger to investigate into what he called the 'essence' of technology.

The very question characterizing the later work-why being allegedly does not show itself to us today as a concern for thinking-nicely points us to the idea that there are different ways in which things can show up for us, including indeed being itself. This idea of a way in which things appear or are disclosed (Weise des Entbergens) in fact marks the core of Heidegger's later thoughts about being and technology. ${ }^{10}$ To understand this, we may start with something we can all readily observe:

\footnotetext{
9 'Das primär Befragte in der Frage nach dem Sinn des Seins ist das Seiende vom Charakter des Daseins. Die vorbereitende existenziale Analytik des Dasein bedarf selbst ihrer Eigenart gemä $\beta$ einer vorzeichnenden Exposition und Abgrenzung gegen scheinbar mit ihr gleichlaufende Untersuchungen [...]. Auf dem Boden der Analyse dieser Fundamentalstruktur wird eine vorläufige Anzeige des Seins des Daseins möglich' (SZ 41).

10 "Die Technik is also nich bloß ein Mittel. Die Technik ist eine Weise des Entbergens" (FT 16), i.e., a way of things showing up. Also: "Die Frage nach der Technik ist die Frage nach der Konstellation, in der sich Entbergung und Verbergung, in der sich das Wesende der Wahrheit ereignet" (FT 37).
} 
that the very same things can appear quite differently to different people. If, for instance, I am familiar with a certain song played on the radio, and you are not, then the song is bound to appear differently to you than to me. Likewise, we can imagine people from different cultures perceive the same objects differently. This need not necessarily be a matter of plain recognition. Standing at proximal distance to an acquaintance can be comfortable for one person and less so for another-yet neither is here at failure of recognizing any particular thing. We can explain such and other cases by saying that people have different background understandings or, to use phenomenological jargon, to say that they stand in different cultural horizons. It is due to our standing in complexly shaped cultural horizons that we are able to see the same things, yet see them in surprisingly different ways.

Dreyfus (1993), in an attempt to simplify matters, connects Heidegger's later concerns about being to such background understandings shaped by largely implicit cultural norms and practices. Dreyfus suggests the distinction between things appearing and the way they appear matches well Heidegger's differentiation of beings and being. ${ }^{11}$ What explicitly comes to view in experience is, very generally speaking, things. What does not really come to view yet is tied inherently to the appearing of things is the implicit horizontal understanding within which those things doom up. Now these two sides are of course never entirely distinct. In fact there exist no 'bare things' which stand out of a cultural horizon in utter indifference to that horizon. ${ }^{12}$ Not only is everything caught up in a culturally and historically shaped way of appearing. Moreover, Heidegger thinks things are also intrinsically shaped by that horizon, that is: they are determined in their very thingness by the elusive operations of cultural background forces. In other words, even the idea of a 'bare thing' universally understood is really only part of a culturally shaped horizon.

We can come a long way when we interpret 'being' for Heidegger as the implicit background structure set by cultural practice and historical situatedness. Since, as we have just seen, the being of things - so the implicit way they appear-is not radically distinct from those things but intrinsically determines them in their manner of appearing, both are always necessarily in some way co-given. In other words, wherever there are things, being co-appears (i.e., things cannot but be within and shaped by a cultural world-horizon). Now, given the great variations between cultures and ages, we can imagine one epoch of history having a closer 'relation to being' than others. This relation to being amounts plainly to the awareness of the necessary cogivenness of being. Put the other way around, a close relation to being would mean having an implicit understanding that things are not just things. A contrasting case is then also conceivable, namely one in which a background understanding would prevail whose interpretative scheme is so forcefully dominant that all concerns about

\footnotetext{
11 Not unrelatedly, Dreyfus further claims that Heidegger's notion of being can be affiliated with the concept of paradigm as developed by Kuhn in his 1962 The Structure of Scientific Revolutions.

12 It is not worth going into the specific case of universals in mathematics and logic here. Heidegger, at any rate, does not believe such ideal objects can transcend the finite temporality of the subject in its finite world-horizon. Husserl most likely does not either, although he is certainly more careful than Heidegger to acknowledge the unique 'omni-temporal' structure which ideal objects exhibit.
} 
being seem senseless. In such a particular day and age, the only things that would be granted important and real would be plain things.

This is, in essence, Heidegger's critique of technology. It is a criticism of what I just called the 'interpretative scheme' which prevails in modern western culture. According to Heidegger, things show up for us in a particular way which was unknown to most previous generations of people. The same things can appear to us and to people of past ages, but the ways in which they do so can be different. To us alone do they appear through the lens of technology. With the term 'technology,' Heidegger does not mean plain tools or instruments but rather a very general and implicit way in which things presumably appear. He calls this peculiar scheme the 'essence' of technology to contrast it with technology in the mundane 'anthropological' sense of any particular group of things or characteristic thereof. ${ }^{13}$ The 'essence' of technology, then, does not point to any instance of technological manipulation, but to a very general horizon of understanding which has come to prevail and which forces itself on all things, our interactions with them, and our thinking about them.

Most of the other important concepts the later Heidegger develops in his writings on technology - most notably 'enframing' (Ge-stell), 'standing-reserve' (Bestand), 'destiny' (Geschick), and 'challenging-forth' (herausfordern)—can be explained on the basis developed so far. First, by 'enframing,' Heidegger means precisely that interpretative scheme or frame shaped by the essence of technology. It thus captures the general way things are manifest. ${ }^{14}$ Closely related, 'standing-reserve' denotes a central characteristic of such manner of appearing of things in our contemporary technological enframing, namely their standing ready for use, for exploitation (FT 20). The world now appears as a collection of objects on standing-reserve; they are plain things at our service; technological opportunity.

Third, to understand the rather idiosyncratic idea of 'destiny,' we need to take note that no interpretative scheme is a purely subjective matter. It is shaped by cultural and historical forces that lie beyond the power of the individual. Any culture is therefore destined to look at the world in a certain way, in other words, to have their distinctive way of letting things appear. This way itself can be either heeded carefully or altogether taken for granted and ignored. In neither case, however, can it be controlled freely, which means man's 'relation to being' (to the way things present themselves) is to a large extent an inevitable fate. ${ }^{15}$ This, of course, restrains

\footnotetext{
13 "Die Technik ist nicht das gleiche wie das Wesen der Technik [...] Die gängige Vorstellung von der Technik, wonach sie ein Mittel ist und ein menschliches Tun, kann deshalb die instrumentale und anthropologische Bestimmung der Technik heißen" (FT 9-10).

14 “'Ge-stell' heißt die Weise des Entbergens, die im Wesen der modernen Technik waltet und selber nichts Technisches ist" (FT 24); "Es ist die Weise, nach der sich das Wirkliche als Bestand entbirgt" (FT 27).

${ }^{15}$ Heidegger uses the example of Plato as an illustration: "Daß sich seit Platon das Wirkliche im Lichte von Ideen zeigt, hat Plato nicht gemacht. Der Denker hat nur dem entsprochen, was sich ihm zusprach" (FT 21). In other words, Plato did not himself control the way things appeared to him; he only described how he saw it. Likewise, "so ist denn die moderne Technik als das bestellende Entbergen kein bloß menschliches Tun” (FT 22-23); "Menschliches Tun kann nie unmittelbar dieser Gefahr begegnen” (FT 38).
} 
Heidegger's space to construe a solution to the problem of technological enframing, which will concern us later.

Lastly, the 'essence' of technology, as a way of appearing, is also characterized by Heidegger in terms of a 'challenging'. This concept is closely related to the concept of standing-reserve. The fact of things appearing as standing-reserve makes that it becomes easy for us to use and exploit things in ways which could be said to 'challenge' their natural mode of presenting. Technology, so to say, levels them out; it puts all things on a par as exploitable resources. For example, instead of this patch of land calling out to be used for this kind of harvest and the other for another due to their natural characteristics, the land now appears everywhere as something to be challenged in order to make it serve whatever function forced upon it (FT 17-19). To give another example, in other ages, Heidegger thinks, a silver chalice was not like a plastic cup made just in order to drink from it. It was rather, Heidegger claims, that to be drank from. In other words, the silver resource was not 'challenged' when it became molded into a cup; it rather held that potential naturally within the larger cultural scheme of things. The plastic of today's disposable coffee cup, on the other hand, would be the product of a different kind of attitude toward the natural world and our own place therein, which reflects the kind of standing-reserve use-and-dispose-of attitude of contemporary western civilization.

Much of Heidegger's thinking about enframing after the Kehre proceeds through rather eccentric philosophical-etymological reflections. Heidegger believed that by analyzing the changes language undergoes over time he could reveal something of the shifts in the tacit background understandings that prevailed. For one, he famously claimed that techne for the Greeks did not involve the kind of challengingmanipulating of things as it does for us. A different interpretative frame ostensibly ruled here. According to Heidegger, the Greek techne did not signify a challenging but rather a 'bringing-forth' (Her-vor-bringen) (FT 17-18). Technique was not merely an exploitation of things to a certain end-as would be our contemporary way of technological disclosure (herausfordernde Entbergen), but instead more akin to a kind of creatively allowing something to reveal itself. Instrumental praxis here still held a certain connection to the beautiful (FT 38). This is why, Heidegger suggests, techne for the Greeks included not just technology but likewise the arts. Art was not a part of techne because art was technological in our contemporary sense, but precisely because technology itself was a creative bringing-forth just as art is.

In another one of his philosophical-etymological inquiries, Heidegger claims that the technological way of relating to things (in terms of challenging and standingreserve) can be traced back specifically to the advent of early modern science. ${ }^{16}$ It is not, however, as one might expect, modern science which steered the course of this development. Instead, Heidegger suggests, it is because the technological enframing became dominant that exact science was called forth. This seems to make exact science derived from the 'essence' of technology, rather than technology being some form of applied science as most are now probably prone to understand it. It seems

\footnotetext{
16 "Dementsprechend zeigt sich das bestellende Verhalten des Menschen zuerst im Aufkommen der neuzeitlichen exakten Naturwissenschaft" (FT 25).
} 
it could easily be argued against this, however, that the concept of an 'essence' of technology thus drastically inflates; it would have prevailed already before modern science and therewith also before the technological revolutions of the renaissance (see also Wheeler 2011). At other points, Heidegger casts doubts again on this reading, noting that the 'essence' of technology did not 'hold sway already' in early modernity, but rather something closer to an omen (Vorbote) of that made its appearance here (FT 25). ${ }^{17}$

The relation between modern science and technology becomes somewhat clearer if we consider Heidegger etymological interpretations of the concepts of 'reality' (Wirkliche) and 'theory' (Theorie) (WB 47-53). Regarding the first, Heidegger mainly focuses on showing somewhat uncontroversially that the kind of enframing in Greek academic life did not let 'reality' appear as exhaustible in terms of effects and consequences (causa efficiens) (WB 47-48). Regarding the second, he claims that the Greeks did not entertain the kind of objectifying attitude known to moderns which assesses the 'real' as something independently standing over-against (Gegenständlich). According to Heidegger, in seeking to take this kind of objective, noninterfering stance vis-à-vis reality, the moderns actually conceal a fundamental part of reality. Their disinterested outlook is not the non-doing they think it is, but a powerful attitude of challenging-forth (herausfordern) (WB 49-53). Science, then, acts on reality, and over a long period of time shapes the way all things appear, thereby excluding alternative ways of appearing. The analyses of 'reality' and 'theory' thus lead to the same conclusion the critique of technology yielded, namely that our contemporary enframing shallow thinking about important questions concerning ontology in a way ultimately beyond our free control.

Heidegger's critiques of technology and of science therefore interlace. ${ }^{18}$ In fact, technological instrumentality is linked closely to the prevalence of the causa efficiens with the advent of modern science (FT 11-14); the former is even said to subsist in or to be grounded in the causal (beruht im Kausalen). Heidegger further relates the concepts of enframing, challenging, and ordering that belong to the 'essence' of technology directly to causality, objectivity, and mathematical-exact determination as traits of the 'essence' of modern science (WB 53-58). It is, then, not just technology, but the combination of the 'essences' of technology and science which constitutes the imminent threat (Gefahr).

For Heidegger, this threat seems in the end to be almost exclusively ontological; it is the threat of an utter oblivion to the way of appearing itself, i.e., to being. In a sense, the way of appearing which prevails - as things on standing-reserve awaiting our challenging use and as nothing more than causal events in a spatiotemporal

\footnotetext{
17 Elsewhere, Heidegger suggests Descartes played a crucial role in opening up the new technologicalscientific worldview characterized by human domination: "Das Tor in den Wesensbezirk dieser metaphysisch verstandenen Herrschaft hat Descartes mit dem Satz cogito sum aufgestoßen” (GA 6.1, 166).

18 In like manner, Glazebrook (2000) in his book Heidegger's Philosophy of Science identifies Heidegger's essences of technology and science (Glazebrook 2000: 209).
} 
order-covers itself over. ${ }^{19}$ The technological enframing 'hides not only a former way of appearing as bringing-forth, but moreover hides the appearing as such' (FT 31). ${ }^{20}$ More simply put, Heidegger believed it prevents us from seeing that what appears to us as 'real' is only an interpretative scheme. It does not hold the truth about things, but rather conceals the final truth understood as the event (Ereignis) of the openness of things within a culturally determined world-horizon.

Ultimately, Heidegger does not offer any concrete cure to the problem of technology and science as interpretative frame. Its forces are not alterable by the efforts of any individual. New roads or possibly old ones ${ }^{21}$ might open themselves in the future if we pay sufficient heed to the problem. The sciences themselves, Heidegger contends, are too segregated to offer solutions; they are confined to their restricted fields of inquiry beyond which they may not ask (WB 49-58). As the German idealists of the early nineteenth century, Heidegger alludes to art as a place to look for new possible ways of things showing themselves, but does not elaborate the point further (FT 36).

It remains at this point an open question how Heidegger thinks he has justified his preference for one scheme over another. For one, it seems it could easily be argued that the plastic cup discussed earlier also fits neatly within its scheme of practices and ways of appearing. If indeed so, then what enables Heidegger to reject it? What warrants the apparent conservative appeal to the pre-technological/scientific horizon as the preferable one? Why exactly is the technological-scientific worldview considered a threat?

Part of an answer, as was mentioned already, is that Heidegger thinks the technological scheme prevents all things from expressing something like their own unique character (see also Lovitt 1977: xxviii-xxix). Since their relation to us is universalized as a relation of standing-reserve, ${ }^{22}$ we allegedly challenge things rather than allowing them to express themselves - as the examples of the silver of the chalice and the different patches of land illustrate. Second, and this is another side of the same coin, Heidegger thinks the technological-scientific scheme effectively conceals our relation to being. We now only see a totality of things ready at our disposal, and since being is not a thing, the very necessity of thinking about being over against beings is concealed. As W. Lovitt aptly puts it, technology is 'the thinking that degrades Being' (1977: xxxii) - and being is what thinking is all about for Heidegger.

One could, of course, ask for a still deeper justification. Why do we need to let things show something like their own character and why do we need a relationship

\footnotetext{
19 "Sie lassen sogar ihren eigenen Grundzug, nämlich dieses Entbergen als ein solches nicht mehr zum Vorschein kommen" (FT 31).

20 "So verbirgt denn das herausfordernde Ge-stell nicht nur eine vormalige Weise des Entbergens, das Her-vor-bringen, sondern es verbirgt dat Entbergen als solches und mit ihm Jenes, worin sich unverborgenheit, d.h. Wahrheit ereignet" (FT 31).

21 Heidegger refers to the pre-technological horizon as an 'ursprünglicheres Entbergen' (FT 32).

22 "Das Wesende der Technik bedroht das Entbergen, droht mit der Möglichkeit, daß alles Entbergen im Bestellen aufgeht und alles sich nur in der Unverborgenheit des Bestandes darstellt" (FT 38).
} 
to being above anything else? Unlike his former master Husserl, Heidegger does not uphold the ideal of a perfectly rational-responsible community which would allow all things to express their own essence as phenomenology exposes them. For Husserl, for instance, 'material thing' is an 'essence' (an essential way of possible object-presentation for consciousness), and hence also one or more sciences targeting that 'region' are required by a responsible community of people. The same goes for 'consciousness' or 'numbers'; these too are essential ways of object-presentation which, by essence differing from material thingness, require their respective sciences. Husserl can thus warrant the need of essence expression and correlatively can justify criticisms of essence concealments by the normative ideal of a perfectly rational community. Heidegger, on the other hand, thinks the classic philosophical trajectory guided by reason has definitively become inaccessible to modern humanity, and so seems barred from that justificatory route. ${ }^{23}$

Ultimately, Heidegger's critique of the technological-scientific worldview does not appear to involve any arguments for the primacy of our relation to being. It nonetheless seems to presuppose them, since the concealment of that relation is defined as this worldview's principal shortcoming. To be sure, Heidegger elaborated on the importance of the question of being substantially in earlier works. Discussing this would, however, take us too far beyond our current concerns.

\section{Husserl on the Technological-Scientific Worldview}

Whereas Heidegger distinguished between an 'essence' of technology and a closely related 'essence' of science, Husserl's interpretation of the crisis facing western civilization in the 1936-work Krisis der europäischen Wissenschaften limits its focus mostly on the development of what he calls the modern 'idea' of science (Idee der Wissenschaft) from the Renaissance onwards (Hua VI 3). The crisis, as Husserl understands it, is present in his day yet still 'rapidly growing' (Hua VI 14). While there certainly are crises unfolding within the foundations of various sciences, including the formal or exact disciplines, the crisis Husserl has in mind is not one about science. It rather concerns the spiritual foundations of western culture. The reason Husserl focuses predominantly on the idea of modern science nonetheless is that he believes it above everything else has come to shape the way things appear to us, to the extent that it has 'controlled all development of world-considerations until the present day' (Hua VI 54). ${ }^{24}$

Husserl, then, like Heidegger, is well aware that things are seen and interpreted differently by people over different times. He is, in fact, undoubtedly more sensitive to detail in his philosophical-historical reflections than Heidegger. Unlike the

\footnotetext{
23 "Aber mit dem Ende der Philosophie ist nicht auch schon das Denken am Ende, sondern im Übergang zu einem anderen Anfang" (ÜdM 79).

24 "Mit Galilei's mathematisierende Umdeutung der Nature setzen sich auch über die Natur hinausreichende, verkehrte Konsequenzen fest, die von ihr aus so naheliegend waren, da $\beta$ sie alle weiteren Entwicklungen der Weltbetrachtung bis zum heutigen Tage beherrschen konnten” (Hua VI 54).
} 
rather broad and opaque accounts of 'essences' developed by Heidegger, Husserl takes painstaking effort to explain what he means by the idea of science and follows its development through modernity in considerable detail. Yet, much like Heidegger, he understands this idea not as an explicitly articulated one but as governed by unarticulated drives or forces (Triebkräften). ${ }^{25}$ In a way reminding of Heidegger's talk of destiny, Husserl notes that a tacit yet powerful 'direction of will' pervades and governs us (hindurchgehende Willensrichtung). The philosophical-historical enterprise of Krisis der europäischen Wissenschaften therefore requires a peculiar breaking of the 'crust' of the surface of historical events in order to uncover a deeper meaning which did not explicitly surface at the time. ${ }^{26}$ Although a continuous matter of debate, these historical inquiries are most likely not to be considered phenomenological investigations. ${ }^{27}$ They are better understood as forming a philosophical-historical introduction to phenomenology. ${ }^{28}$

Again in accordance with Heidegger, Husserl speaks of the modern idea of science as one which aims at 'controlling' (beherrschen) the 'totality of things generally' (Allheit des überhaupt Seienden). Moreover, it is said the modern scientific image gradually gained a certain control over people, shaping the sorts of questions people feel warranted in asking. Mere sciences of fact, Husserl notes, also make people of facts. ${ }^{29}$ In particular the 'positivistic shrinking of the idea of science' (Hua VI 5) which Husserl sees developing in the second half of the nineteenth century ended up barring us from asking important questions. ${ }^{30}$ These include 'questions of humanity' (Menschheitsfragen) — among others existential-ontological ones pertaining to the meaning of being or human existence ${ }^{31}$ — but also metaphysical or philosophical questions (Hua VI 8), understood generally as those which transcend the world conceived of as universe of mere facts. ${ }^{32}$ The positivism which is the outgrowth of the development of modern science 'decapitates' philosophy (Hua VI 7); it 'threatens to consume' it (Hua V 13). The current inability to ask such questions is

\footnotetext{
${ }^{25}$ Husserl uses the term 'inner drives' (innersten Triebkräften) at several places (Hua VI 54, 75), although contexts suggest this should not be taken in any strict terminological sense.

26 “Wir versuchen, durch die Kruste der veräußerlichten 'historischen Tatsachen' der Philosophiegeschichte durchzustoßen, deren inneren Sinn, ihre verborgene Teleologie, befragend, aufweisend, erprobend" (Hua VI 16). Also: "Es heißt, die sedimentierte Begrifflichkeit, die als Selbstverständlichkeit der Boden seiner privaten und unhistorischen Arbeit ist, wieder lebendig zu machen in seinem verborgenen geschichtlichen Sinn" (Hua VI 73).

27 See especially Morisson (1977), Casement (1988) and Hopkins (2003) for able discussions.

28 Ingarden (1972) is best known for defending this position. It is also reflected in Carr's (2010) more recent suggestion that Husserl regarded phenomenology "as a project of universality that is aware of its own particularity and historicity" (Carr 2010: 99).

29 "Bloße Tatsachenwissenschaften Machen bloße Tatsachenmenschen" (Hua VI 4).

${ }^{30}$ On this point, too, Heidegger is not too far from Husserl. Heidegger saw in Nietzsche rather than in scientific positivism the completion of the historical movement that resulted in the expelling all questions of traditional philosophy.

31 "Gerade die Fragen schlie $\beta$ t sie prinzipiell aus, die für den in unseren unseligen Zeiten den schicksalsvollsten Umwälzungen preisgegebenen Menschen die brennenden sind: die Fragen nach Sinn oder Sinnlosigkeit dieses ganzen menschliches Daseins" (Hua VI 4).

32 “Alle diese 'metaphysischen' Fragen weit gefaßt, die spezifisch philosophischen in der üblichen Rede, übersteigen die Welt als Universum der bloßen Tatsachen" (Hua VI 7).
} 
essential to Husserl's take on the crisis; they are what previously animated scientific inquiry, no matter how tacitly, thereby providing an overall sense of direction and a kind of positive spirit or 'swing' (Schwung) to their progressions (Hua VI 7).

The structure of Husserl's diagnosis of the crisis can be summarized as follows. In brief, while the institution of the modern idea of science in the Renaissance made possible the new positivistic sciences, the latter have come to control the spirit of contemporary European humanity ${ }^{33}$ in general (Geistes des neuzeitlichen europäischen Menschentums überhaupt) (Hua VI 59). This means Husserl focuses on the historical development of the idea of modern science and its positivistic outgrowth in order to elucidate the meaning of the crisis, which in turn is a crisis of spirit rather than of science. Exactly as Heidegger suggested some 15 years later, Husserl notes that the sciences, because they are locked within their own regional domains, are unable to address concerns of spiritual humanity (Hua VI 4). More crucially still, Husserl thinks they in fact expel them from any possible legitimate form of understanding (Hua VI 5). In other words, the crisis is essentially the holding sway of a certain frame of understanding, historically determined through the idea of modern science, which makes all questions transcending mere facts nonsensical-the same questions which (ironically) once motivated the modern idea of science.

The threat Husserl sees western society faced with thus shares with Heidegger's critique a chief concern for the need for fundamental questioning. But for Heidegger, as we saw previously, the diagnosis and cure were cashed out almost exclusively in ontological terms. His critiques of technology and science said nothing about reason, human responsibility, justice, and so forth; they pertained to our 'relation to being' only. This contrasts in complicated ways with Husserl, for whom the importance of philosophical questions has everything to do with reason, truth, and ethical responsibility. ${ }^{34}$ Husserl does not merely highlight the necessity of a 'questioning thinking' (to borrow a phrase from Heidegger), he also provides detailed answers in other writings based on his own conception of transcendental phenomenology. Before turning to that, however, the diagnosis of the crisis through the idea of science needs to be clarified further here.

Husserl traces the idea of modern science back to the Renaissance, at first in particular to Galilei. ${ }^{35}$ The unique impulse Renaissance philosophy gave to western civilization, he claims, rests on the institution of a simple but revolutionary double idea (Hua VI 5 19-20). It is the invention of a new way of conceiving of the world we

\footnotetext{
33 The term 'Europe' for Husserl is not a geographical notion, but, as Buckley also rightly pointed out, refers to "nothing less than a form of life guided by scientific rationality [...]. Europe is a spiritual designation, referring to a life led by the ideal of universal, scientific rationality" (Buckley 1992: 27).

34 See particularly Melle $(1991,1998)$ for a discussion of Husserl's ethical views and the role it takes in his philosophy.

35 The emphasis on Galilei does not figure prominantly in any of Husserl's earlier writings. Buckley (1992: 42) suggests the conception of Galilei as father of the new worldview can be traced at least to Windelband's Die Geschichte der neueren Philosophie, which Husserl had read.
} 
live in as one consisting of a totality of things forming a single rational unity, ${ }^{36}$ and more specifically, a rational unity that is controllable in its entire determinable being through one universal mathematical science. ${ }^{37}$ Thus Husserl's quest at first becomes to show how mathematics is employed and conceived of in relation to the study of nature, which he traces from Galilei and Descartes through to Spinoza, Leibniz, Locke, Berkeley, and finally to Kant (Hua VI 20-104).

The theme of Husserl's investigation, however, is not the content matter of mathematics itself, but the development of the tacitly operative idea of modern science as a universal mathematical science of nature. Husserl does not lump centuries of developments into one idea of technological or scientific conceiving, but carefully treats different thinkers and the mark they left on the contemporary scientific worldview separately. Yet again in a vocabulary reminding of the later Heidegger, he speaks of the great philosophers of modern science as 'concealing and unconcealing' (entdeckender und verdeckender) geniuses (Hua VI 53). Especially when their ideas are taken over by next generations, tacit 'shifts in meaning' (Sinnverschiebungen) take place (Hua VI 46). Just as Heidegger analyzed words to reveal shifts in background understandings, Husserl claims that what superficially appears to be one scientific enterprise can acquire a different meaning over time. It is contextualized differently; set within a changed horizon of sense (verwandelten Sinneshorizont) (Hua VI 48), with the original thinking (ursprüngliches Denken) being tacitly covered over.

This process, according to Husserl, makes it possible for science ultimately to become mere techne. ${ }^{38}$ In fact, as Husserl further remarks, the threat of science becoming mere techne is inherent to the very essence of the new science. Nature can be controlled by the new mathematical science only through a 'meaning-emptied technical thinking' (sinnesentleertes technisches Denken) (Hua VI 57). This emptying of meaning is simply a necessary consequence of its thoroughly formalized method. The increasing formalization of exact natural science is simultaneously a concealing of the original meaning which the scientist, 'in the best case a brilliant technician in the respective method,' is generally not capable of retrieving. ${ }^{39}$ To lay bare the development of the changing sense of the idea of modern science thus calls for a new kind of historical and responsible critique beyond the scopes of the sciences-which is the partial aim of Krisis der europäischen Wissenschaften. ${ }^{40}$

\footnotetext{
36 "Kein Wunder, daß wir schon bei Descartes die Idee einer Universalmathematik finden [...]. Demnach bekommt korrelativ Welt und Philosophie ein völlig neues Gesicht. Die Welt muß an sich eine rationale Welt sein, im neuen Sinne der Rationalität” (Hua VI 62).

37 '[D]ie Idee, da $\beta$ die unendliche Allheit des überhaupt Seienden in sich eine rationale Alleinheit sei, die korrelativ durch eine universale Wissenschaft, und zwar restlos, zu beherrschen sei" (Hua VI 20).

38 Just as Heidegger, Husserl uses both the Greek word techne and the German word Kunst, meaning 'art' in English (Hua VI 57).

39 "Aber der Mathematiker, der Naturwissenschaftler, günstigerfalls ein höchst genialer Techniker der Methode [...] ist eben normalerweise durchaus nicht befähigt, solche Besinnungen durchzuführen" (Hua VI 57).

40 'Ein verantwortliche Kritik'; 'eine Kritik eigener Art'; 'eine historische Rückbesinnung' (Hua VI 73).
} 
Originally, Husserl notes, the modern idea of a universal mathematical science of nature had its roots in the practical measuring activities of the pre-scientifically experienced surrounding world (vorwissenschaftlich-anschaulichen Umwelt) (Hua VI 24). The things of the experienced surrounding world already have their own 'habits' and 'typicalities'; their typical ways of appearing and relating to each other (Hua VI 28). This goes for their shapes, qualities, patterns of behavior, interactions, and so on. Phenomenologically speaking, to perceive is always to have something given in a pattern of future directed expectations; it involves complex 'predictions' of future occurrences, although these predictions are of a distinctively passive kind. However, things do not for that reason appear as structured according to absolute laws. The very idea that all things would stand under such laws naturally has no place in pre-scientific experience at all.

The great event of modern science, according to Husserl, is that it conceives for the first time of that idea; that the endless field of experienced objects with their pregiven typicalities and habits is determinable through its approximation to ideal systems in a way universally accessible to anyone. The Greeks, Husserl thinks, lacked that idea. To be sure, they had mathematical systems, and these were at various instances applied to nature. Yet Husserl maintains that the relation of pure mathematics to the world of everyday experience was here framed differently. Natural science in the modern sense is not just mathematics occasionally applied to nature. It is a distinctive idea, which later becomes an implicit interpretative scheme, namely that the totality of endlessly experienceable nature can be made to fit in ever-increasing exactitude universally valid mathematical systems. It is only relative to that idea that the geometries of the Greeks can be contrasted as being 'world-estranged' (weltentfremdete ideale Geometrie) (Hua VI 31).

Importantly, this idea is not immediately conceived of with regard to the totality of worldly beings. At first, it is applied to the spatiotemporal manifold only. The new science of nature initially manages to establish exact results solely in regard of shapes (Gestaltenmathematik). This is ultimately due to the fact that, phenomenologically speaking, pre-scientific experience constitutes all things with extension for all of us (Hua VI 30). Yet, Husserl notes, the question soon arises whether something similar could not also hold for the concrete world in all its conceivable determinations. ${ }^{41}$ That is to say, that a mathematical index could hold for any possible determination of res extensa; for color, sound, warmth, and so on (Hua VI 35). This idea, Husserl claims, while today treated as 'unquestionably obvious' (fraglose Selbstverständlichkeit) (Hua VI 35), was not yet wholly transparent to Galilei who first instituted the modern idea of science.

\footnotetext{
41 "Mu $\beta$ ähnliches nicht für die konkrete Welt überhaupt möglich sein? Ist man gar schon vermöge der Rückwendung der Renaissance zur alten Philosophie - wie Galilei - in der sicheren Überzeugung der Möglichkeit einer Philosophie, einer objektive Weltwissenschaft leistenden Episteme, und hatte es sich eben schon gezeigt, da $\beta$ reine Mathematik, angewandt auf Natur, das Postulat der Episteme in ihrer Gestaltensphäre vollendet erfülle: mußte da für Galilei nicht auch vorgezeichnet sein die Idee einer in gleicher Weise nach allen anderen Seiten konstruktiv bestimmbaren Natur?" (Hua VI 31).
} 
Thus, Husserl suggests, the idea of a mathesis universalis in Leibnizian fashion came to be conceived; a single universal science for the totality of beings in all their natural-objective determinations. The obvious problem this new idea faces is, however, that it is unclear how the 'sensible qualities' (sinnliche Qualitäten) of the objects of the experienced surrounding world could approximate an ideally constructed index in the same direct manner as their extension can (Hua VI 31-32). Colors, sounds, temperatures, and so on, are not like spatiality measurable directly in relation to any mathematical system accessible to all which they can approximate in increasing exactitude (Hua VI 32-33). ${ }^{42}$ This, too, of course, has its particular phenomenological foundations, but that lies beyond the scope of the historical-introductory function of Krisis der europäischen Wissenschaften.

The very problem of the mathematizability of sensible qualities is absolutely central to Husserl's tracing of the roots of the crisis. Husserl thinks this problem, which is originally of a theoretical-methodological nature and furthermore wholly indebted to the guiding ideal of a single universal science of the totality of nature, undergoes peculiar shifts of sense over time; it becomes appropriated ontologically and epistemologically. In short, Husserl believes the theoretical problem of the exact determination of extra-spatiotemporal features reifies the idea that through all changes in subjective apprehension there is given one true world, namely that world which is universally knowable in mathematical exactitude by abstracting from all supposedly merely subjective-contingent qualities (Hua VI 32). In other words, since extraspatiotemporal features of objects cannot be directly correlated to ideal poles of pure mathematical systems, they are no longer considered part of the real. The limited scope of possible success of the modern scientific method thus leads to a confusion of the restrains of method for the actual object under scrutiny. It is a case of the concept or method become reality. ${ }^{43}$

This is, in brief, the first important change of sense which the modern idea of science made possible. It is, Husserl thinks, the break of the original unity of the human-world relation in pre-scientific world-experience into an 'objective' and a 'subjective' part as a result of the problem of bringing extra-spatiotemporal features - not only sensory qualities but also all cultural productions (Kultureigenschaften) and ultimately the psyche or consciousness itself-in direct correspondence to a mathematical index. This is cashed out, roughly speaking, first in the distinction between primary and secondary qualities for the empiricists and later between pure and empirical concepts for Kant. This way, the new science first brings with it a 'complete metamorphosis of the idea of world in general' (Hua VI 61). ${ }^{44}$ The

\footnotetext{
42 "Aber die rein in diesen fundierten qualitativen Konfigurationen sind keine Analoga der raumzeitlichen Gestalten, sind nicht eingeordnet in eine ihnen eigene Weltform. Die Limesgestalten dieser Qualitäten sind nicht in analogem Sinne idealisierbar, ihre Messungen ('Schätzungen') nicht auf entsprechende Idealitäten einer konstruierbaren, einer schon in Idealität objektivierten Welt zu beziehen" (Hua VI 33).

43 "Das Ideenkleid macht es, da $\beta$ wir für wahres Sein nehmen, was eine Methode ist" (Hua VI 52).

44 “[D]aß die Auffassung der neuen Idee 'Natur' als einer abgekapselten, einer real und theoretisch in sich geschlossenen Körperwelt, alsbald eine völlige Verwandlung der Idee der Welt überhaupt mit sich führt" (Hua VI 61).
} 
original unity of the human-world relation is overlaid by a theoretical distinction which shapes and constrains what we think of as real.

The second, related consequence that is of perhaps even greater importance to Husserl is the likewise 'now obvious' distinction which has come to prevail between a priori mathematical-ideal and a posteriori natural-scientific knowledge. According to Husserl, the successes of pure mathematics and the a priori certainty of its results contrast with the laws of nature which, although thoroughly mathematical themselves, are considered a posteriori for being only inductively accessible and derived from factual experiences. The two kinds of knowledge seem to oppose each other naturally: a priori mathematics of ideal space and time, and-although employing a priori mathematics-impure natural science (Hua VI 55-56). It is on grounds of this conception that Kant develops the early modern ontology of primary and secondary qualities in epistemological terms. That is to say, we find the same underlying thought now expressed in terms of our mind's access to the world. It leads to the idea that while we allegedly possess an 'inborn' capacity for a priori insight in mathematics concerning space and time, we have no such a priori evidences regarding anything that involves any concrete worldly content because of our inductive access to all laws governing that. This conception, therefore, still cannot unify the human-world relation because the notion of a priori gets wrongly restricted solely to mathematics. ${ }^{45}$

In short, then, Husserl believed the successes of modern mathematical natural science led to the reconceptualization of the human-world relation as divided into subjective ('illusory') sensory fillings of objects and objective ('real') spatiotemporal determinations, while dividing the cognitive faculty in a posteriori knowledge about nature and a priori knowledge exclusively concerning the mathematics of space and time. Kant's transcendental theory is thus deemed no exception to the ruling paradigm. For Husserl, it rather rephrases the same idea in transcendental-epistemological terms, qualifying on supposedly a priori grounds (through a transcendental

\footnotetext{
${ }^{45}$ Husserl deems the restriction of a priori evidence to mathematics as in Kant a 'mythical' construction (Hua VI 116-118). At the point of writing Krisis der europäischen Wissenschaften, Husserl thought he had already clarified the essence of a priori evidence elsewhere in his elaborate phenomenological work on pure imagination. In brief, Husserl maintained that a priori refers to pure possibility, i.e., to pure imaginative possibility in detachment from actuality. Any a priori proposition is one which holds valid in pure possibility, and therefore 'prescribes rules' to the actual (as an instance of the possible). Euclidean geometrical propositions are examples of regionally valid a priori propositions (valid within a Euclidean manifold). But, Husserl continues, "there is not the slightest reason to consider the methodological structure of a priori thinking [...] as an exclusive property of the mathematical sphere" (Husserl 1997a: 353). This is because the capacity for the free variation of possible instances in pure imagination which is involved in a priori cognition is 'everywhere the same' (Husserl 1997a: 354). Therefore, "from every concrete actuality, and every individual trait actually experienced in it or capable of being experienced, a path stands open to the realm of ideal or pure possibility and consequently to that of a priori thinking" (Husserl 1997a: 353f.). Phenomenology itself is an example of a non-mathematical a priori discipline.
} 
examination of a priori 'inborn' forms) as unscientific all propositions not construed out of the a priori spatiotemporal manifold.

Simultaneously, Husserl notes, great problems for the development of a rational psychology - in other words, for a mathematical index for the study of subjective consciousness - are brought into the horizon of the modern idea of science. ${ }^{46}$ Guided by the ideal of one universal science of objective nature, the psyche too is enframed as an object in the causal world order. But this problem, although leading to the allegedly flawed naturalist epistemologies of in particular Locke and Hume, simultaneously makes something good possible. Specifically under the unprecedented severity of the Humean threat of skepticism the advent of an alternative, indeed contrary, philosophical worldview is brought into being, namely that of transcendental philosophy (Hua VI 70-71).

As Husserl develops in many of his works, the naturalistic-positivistic sciences, here understood as the outcome of the modern idea of an all-encompassing mathematical natural science, depart from a naïve acceptance of a world of self-existing objects. ${ }^{47}$ According to Husserl, in a completely evolved philosophical naturalism, reason starts and terminates with those self-existing objects. ${ }^{48}$ Beyond them, there are no longer meaningful questions possible. Transcendentalism, on the other hand, says that the sense of independent being the world of natural science has just is an accomplishment of subjective experience. ${ }^{49}$ Thus, instead of starting with the object and from there running against the wall of subjectivity, it starts with the latter and appropriates the objective world rightly as a sense-accomplishment of subjective experience. Naturalism, as Husserl maintained from very early on, shall in fact never be able to describe the subjective life of consciousness in mathematical exactitude. Even if perfect mathematical indices would be developed, the results would inevitably yield mere correlations (see, especially, Hua V 16-19). They would bypass the essence of consciousness itself, which Husserl thinks is inherently non-spatial—much like the idealities of mathematics are not anywhere in three-dimensional space.

The rest of the history of philosophy after Kant, Husserl notes, can be characterized as a battle between naturalism and transcendentalism (Hua VI 71). The first

\footnotetext{
46 While the modern conception of mind starts with Descartes, Husserl sees in Locke-whom he appears to hold in particularly low regard-the first systematic attempt at an objective-naturalistic epistemology and theory of consciousness (Hua VI 85-88).

47 "Die naivität der Rede von 'objektivität', die die Erfahrende, erkennende, die wirklich konkret leistende Subjektivität ganz ausser Frage lässt, die Naivität der Wissenschaftslers von der Natur, von der Welt überhaupt, der blind ist dafür, das alle die Wahrheiten, die er als objektive gewinnt, und die objektive Welt selbst, die in seinem Formeln Substrat ist [...] sein eigenes, in ihm selbst gewordenes Lebensgebilde ist" (Hua VI 99).

48 “Alle objektive Weltbetrachtung ist Betrachtung im 'außen' und erfaßt nur 'Außelichkeiten', Objektivitäten" (Hua VI 116).

49 "Das Charakteristische des Objektivismus ist, daß er sich auf dem Boden der durch Erfahrung selbstverständlich vorgegebenen Welt bewegt [...]. Damit werde das letztlich Seiende erreicht, hinter das zurückfragen keinen vernünftige Sinn mehr hätte [...]. Der Transzendentalismus dagegen sagt: der Seinssin der vorgegebenen Lebenswelt ist subjektives Gebilde, ist Leistung des erfahrenden, des vorwissenschaflichen Lebens. In ihm baut sich der Sinn und die Seinsgeltung der Welt auf' (Hua VI 70).
} 
movement finally strands in the positivistic sciences; the other terminates in transcendental phenomenology. One is responsible for the crisis; the other the solution to it. Scientific positivism, starting and terminating with objects, cannot explain but estranges from consciousness, ideal laws, and indeed all fundamental philosophical concerns-particularly the 'mystery of all mysteries' (Rätsel aller Rätsel): the essential correlation of 'thinking and being' (Vernunft und Seiendem überhaupt), of subjectivity and objectivity (Hua VI 12). Which one wins the battle, as Husserl puts it somewhat dramatically, is to determine whether the European spirit is reborn out of true philosophy or whether the crisis means the downfall of western civilization. ${ }^{50}$

At this point it would be fair to ask, as we did with Heidegger, what justifies Husserl's negative evaluation of the development of the idea of modern science. Here, however, the answer seems to be quite simple: for Husserl modern science plainly ended up getting things wrong. It misconstrues the way the human-world relation is essentially constituted while further preventing us from asking deeper questions about that, thereby (as Heidegger also said) peculiarly reifying its own flawed perspective. This is surely not to say that Husserl is against the natural sciences as such. He only criticizes the scientific worldview as the dominant way of conceiving of reality, insofar as it is an irrational and therefore irresponsible worldview.

This leaves it open, of course, how exactly Husserl warrants the claim that it is wrong. In this respect, Husserl's critique is, as Heidegger's, tied cohesively into the rest of his philosophy. Its justification ultimately depends on his account of transcendental phenomenology as the professed true end-form (Endstiftung) of the development of the idea of modern science. While addressing that obviously lies beyond the scope of this paper, it is worth considering some important aspects briefly to shed light on the viewpoint from which Husserl criticizes the technological-scientific outlook.

In contradistinction to Heidegger's, Husserl's critique is driven by the pursuit of pure reason and pure human responsibility through the development of a universal first philosophy. Husserl's idea of a first philosophy is that of a systematic, ideal and thereby universally shareable system which is capable of clarifying the final sense of the human-world relation in all its essential aspects. The validity of its propositions must further be based on indubitable (a priori) evidence. This task, the details of which are not addressed in Krisis der europäischen Wissenschaften but in other works, presupposes an absolutely certain beginning. As is well known, Husserl claims to have found this in the so-called a priori correlation of subject and object (Hua VI 161). The a priori correlation, the proof of which is intricate and continuously revisited by Husserl, states that there can be no object without

\footnotetext{
50 "Die Krise der europäischen Daseins hat nur zwei Auswege: Den Untergang Europas in der Entfremdung gegen seinen eigenen rationalen Lebenssinn, den Verfall in Geisfeindschaft und Barbarei, oder die Wiedergeburt Europas aus dem Geiste der Philosophie durch einen den Naturalismus endgültig überwinnenden Heroismus der Vernunft" (Hua VI 347).
} 
consciousness. ${ }^{51}$ Even the idea of an object or world independently of consciousness requires a consciousness entertaining the idea; it too is a sense accomplished by a consciousness. Without dwelling on the details, the task of phenomenology then is to take that correlation seriously and to study all the essential structures of all conceivable subject-object relations precisely as they are manifest.

In Krisis der europäischen Wissenschaften, the unity of the human-world relation is cashed out not in terms of intentionality (as in Ideas I from 1913), but through the concept of 'lifeworld' (Lebenswelt): the 'continuously as-real given world experienced in our concrete world-life, ${ }^{52}$ The lifeworld, a richly multi-faceted but also relatively elusive concept,${ }^{53}$ denotes something like the everyday world of human praxis. It is not the ultimate ground of all world-constitution, but rather points to the default place human beings have in the world. Even the natural scientist is ultimately a human being living in the experienced everyday world (in dieser Welt lebende Mensch), and the questions she asks can never pertain to more than the world of real and possible experiences (wirklicher und möglicher Erfahrungsphänomene) (Hua VI 50). Yet the lifeworld is at risk of being forgotten by the positivistic sciences which reduce the world to a mind-independent collection of facts.

Although sometimes taken so, the lifeworld does not seem to be the focal point of Husserl's Krisis der europäischen Wissenschaften. It is one of many things whose true essence is neglected by fact-oriented science, next to among others subjectivity itself, ideal laws, the subject-world correlation, and moral values-none of which exist in the stricter naturalistic sense. Ultimately, all these problems-which Husserl thinks are unsolvable from a naturalist viewpoint-point to transcendental phenomenology as the ultimate responsible philosophy which, unlike the naturalist worldview which has come to rule, can accommodate in scientific rigor the being of anything just as it presents itself, prior to overlaying it with a technological-scientific scheme which would prevent them from expressing their true essence.

Carr (1974) and Moran (2012) both suggested that Husserl vastly over-estimated the potential of transcendental phenomenology by positing it as cure for the crisis. Admittedly, it is hard to imagine how the phenomenological science we know from Husserl's collections of manuscripts could save western

\footnotetext{
${ }^{51}$ This idealist commitment is expressed in near to all Husserl's writings from Ideen I (1913) onwardsalthough the idealist turn can be traced much earlier to the winter lectures of 1906-1907, see also Melle (2010). For instance in Ideen I: everything transcendent "muss notwendig Erfahrbar sein [...] und nicht bloß für ein durch eine leere logische Möglichkeit erdachtes, sondern für irgendein aktuelles Ich" (Hua III/1 108); in Cartesianische Meditationen: 'daß diese Begriffe in ihrer formal-ontologischen Allgemeinheit eine universal Strukturgesetzmäßigkeit des Bewußtseinsleben überhaupt indizieren, vermöge deren allein Wahrheit und Wirklichkeit für uns Sinn haben und Sinn je haben können' (Hua I 94-95); in Natur und Geist: 'die Welt, jede erdenkliche Welt überhaupt ist nur denkbar als relativ, relativ zu der Wirklichkeit der Bewusstsein' (Hua XXXII 78); in the lectures Einleitung in die Philosophie: "Gegenständlichkeit und Subjektivität stehen a priori in Beziehung zueinander. Jeder Gegenstand ist a priori beziehbar auf irgendwelche Ichsubjekte" (Hua XXXV 260); and in Transzendentaler Idealismus: "Bewusstsein und Sein must irgendwie zusammenhangen" (Hua XXXVI 56).

52 "[D]er Lebenswelt: der in unserem konkreten Weltleben uns ständig als wirklich gegebenen Welt" (Hua VI 51).

${ }^{53}$ See especially Carr (1970) for a discussion of the concept of lifeworld.
} 
civilization. Yet to focus on those meticulous phenomenological analyses would be, I would argue, to miss the crux of his criticism. The crisis, for Husserl, as for Heidegger, is about a certain way of framing things. This way of framing, Husserl maintained, cloaks the true essence of certain things and estranges us from deeper inquiries. ${ }^{54}$ For Husserl as perhaps for any honest philosopher, the only way to responsibly disprove this frame and to open a new road beyond it would be to show that it is incorrect and to provide a better alternative. Thus considered, there can be no responsible solution to the crisis other than of the kind Husserl sought to offer: that of a new, rational, and thoroughly transparent philosophy.

\section{Conclusion}

The extent to which Husserl and Heidegger oppose each other with regard to what they take to be genuine philosophy profoundly marks their different solutions to the crisis resulting from the technological-scientific worldview. For Husserl, philosophy equals responsibility — which can only be achieved through reason—and as such it is both an inherently rational as well as an ethical enterprise. It demands loyalty to the things themselves, involves rigor and precision to maintain a character of universality, and requests an unconditional will to determine life individually and socially in accordance with laws of reason. For Heidegger, by contrast, the solution to the crisis is no longer deemed to lie in the hands of the rational philosopher-hence the famous remark that at this point in time 'only a God can save us' (nur ein Gott kann uns retten). ${ }^{55}$ Philosophy should instead move to a questioning and heedful thinking about being in the most general of terms.

Within this archetypical opposition, however, we found a deeper convergence of ideas regarding technological-scientific enframing. This holds for certain methodical principles of their respective inquiries-such as the idea that we view things differently over time, that we have limited control over this, and that we are capable of tracing shifts in background understandings through special historical analysis. But it also holds for the content of their criticisms. Both philosophers identify a threat in the way science and technology yield a meaning-emptied technical thinking. For both, the problem lies not in science or in

\footnotetext{
54 See also Hadjioannou (2019: 66) who yields a position quite opposite to the one I develop here, by claiming that Heidegger shows that Husserl's phenomenology would fall prey to the same kind of rationality and care for certainty that characterized modern philosophy and mathematical science. He also claims that since Husserl's phenomenological attitude is theoretical, it is essentially just like natural science, and argues that Husserlian phenomenology speaks "the formal language of assertoric logic and of mathematical formulae" (Hadjioannou 2019: 68). I hope my expositions in this paper make clear that such claims seriously misrepresent Husserl's philosophy. A thoroughly rational approach does not, for Husserl, necessarily amount to a mathematical or objectivist approach. Hadjioannou's recent contribution does not, to my mind, sufficiently take into account Husserl's own original criticism of the technologicalscientific worldview - although it does shed important light on how Heidegger (mis)read Husserl.

55 In the 1966 der Spiegel interview (Heidegger 1981).
} 
technology itself, but in how they have tacitly come to shape our sense of the real and the sorts of questions we feel warranted in asking. For Heidegger as for Husserl, genuine, non-technical, philosophical thinking can be a matter neither of mere logical inference nor of plain empirical facts. ${ }^{56}$ Philosophy must go beyond the sciences in order to provide a meaning which they themselves must methodically exclude.

Notwithstanding these deeper similarities between Heidegger's critique of the technological-scientific worldview and Husserl's some 15 years earlier, one cannot avoid the impression that at least in terms of detail of historical-exegetic analysis Husserl's exposition significantly surpasses Heidegger's. Heidegger's thought on the technological-scientific worldview does not pursue exactitude like Husserl's. Central notions such as the 'essence' of technology and of science arguably remain underdeveloped; they are supposed to cover centuries of modern history, their precise signification as well as exact historical origin being up to the reader's guess. Ultimately, in the light of its contrast to Husserl's discussion, this could lead one to wonder what substantial theoretical contributions Heidegger's historically influential work on technology really makes. Although potentially unsatisfactory, one possible (and charitable) response to this would once more point to Heidegger's original departure from Husserl regarding what makes a genuine philosopher. The philosopherfor Heidegger a heeder of being, a task beyond calculative precision, rational systematicity, and the pursuit of reason; for Husserl the 'true rationalist, ${ }^{57}$ the 'real positivist," 58 the "strongest realist, ${ }^{59}$ indeed, the transcendental idealist.

Open Access This article is distributed under the terms of the Creative Commons Attribution 4.0 International License (http://creativecommons.org/licenses/by/4.0/), which permits unrestricted use, distribution, and reproduction in any medium, provided you give appropriate credit to the original author(s) and the source, provide a link to the Creative Commons license, and indicate if changes were made.

\footnotetext{
${ }^{56}$ For Heidegger, genuine thinking can be confirmed nor rejected by logic or facts: "Aber das Einzige, was jeweils ein Denker zu sagen vermag, läßt sich logisch oder empirisch weder beweisen noch widerlegen. Es ist auch nicht die Sache eines Glaubens. Es läßt sich nur fragend-denkend zu Gesicht bringen" (WNZ, 115). For Husserl something similar holds albeit for different reasons. For him, phenomenology (philosophy) is a science of essences-which are not facts but universals - the study of which involves methodically bracketing logical and empirical methods and findings.

57 "Denn von neuem betone ich: wahre und echte Philosophie bzw. Wissenschaft und wahrer und echter Rationalismus ist einerlei" (Hua VI 200-201).

58 “Sagt 'Positivismus' soviel wie ein absolut vorurteilsfreie Gründung aller Wissenschaften auf das 'Positive', d. i. originär zu Erfassende, dann sind wir die echten Positivisten" (Hua III/1 45).

59 "Einen stärkeren Realismus kann es also nicht geben, wenn dieser Wort nicht mehr besagt als: "ich bin dessen gewi $\beta$, ein Mensch zu sein, der in dieser Welt lebt usw., und ich zweifle daran nicht im mindesten' (Hua VI 191); 'Kein gewöhnlicher 'Realist' ist je so realistisch und so concret gewesen als ich, der phänomenologische "Idealist'” (BW 7 16).
} 


\section{References}

Bossert, P. T. (1974). A Common misunderstanding regarding Husserl's Crisis text. Philosophy and Phenomenological Research, 35(1), 20-33.

Carr, D. (1970). Husserl's problematic concept of lifeworld. American Philosophical Quarterly, 7(4), 331-339.

Carr, D. (1974). Phenomenology and the problem of history: A study of Husserl's transcendental philosophy. Evanston, IL: Northwestern University Press.

Carr, D. (2010). The Crisis as philosophy of history. In D. Hyder \& H. J. Rheinberger (Eds.), Science and the life-world: Essays on Husserl's crisis of the European sciences. Stanford: Stanford University Press.

Casement, W. (1988). Husserl and the philosophy of history. History and Theory, 27(3), 229-240.

Crowell, S. (2013). Normativity and phenomenology in Husserl and Heidegger. Cambridge: Cambridge University Press.

Cumming, R. D. (2001). Phenomenology and Deconstruction, Volume 4: Solitude. Chicago: University of Chicago Press.

Dreyfus, H. L. (1993). Heidegger on the connection between nihilism, art, technology and politics. The Cambridge companion to Heidegger (pp. 289-316). Cambridge: Cambridge University Press.

Glazebrook, T. (2000). Heidegger's philosophy of science. New York: Fordham University Press.

Hadjioannou, C. (2019). Heidegger's critique of techno-science as a critique of Husserl's reductive method. In A. J. Wendland, C. Merwin, \& C. Hadjioannou (Eds.), Heidegger on technology. New York and London: Routledge.

Heidegger, M. (1975). Martin Heidegger Gesamtausgabe. II. Abteilung: Vorlesungen 1923-1944, Band 24: Die Grundprobleme der Phänomenologie (1927). Frankfurt am Main: Vittorio Klostermann.

Heidegger, M. (1977). Martin Heidegger Gesamtausgabe I. Abteilung: Veröffentliche Schriften 19141970, Band 2: Sein und Zeit (1927). Frankfurt am Main: Vittorio Klostermann.

Heidegger, M. (1981). Only a god can save us: the Spiegel interview. In T. Sheehan (Ed.), Heidegger: The man and the thinker. Chicago: Precedent Press.

Heidegger, M. (1996). Martin Heidegger Gesamtausgabe. I. Abteilung: Veröfftentliche Schriften 19101976, Band 6.2: Nietzsche. Frankfurt am Main: Vittorio Klostermann.

Heidegger, M. (2000a). Die Frage nach der Technik (1953). In F. W. Von Herrmann (Ed.), Martin Heidegger Gesamtausgabe. I. Abteilung: Veröffentliche Schriften (1910-1970), Band 7: Vorträge und Aufsätze (pp. 5-36). Frankfurt am Main: Vittorio Klostermann.

Heidegger, M. (2000b). Überwindung der Metaphysik (1936-1946). In F. W. Von Herrmann (Ed.), Martin Heidegger Gesamtausgabe. I. Abteilung: Veröffentliche Schriften (1910-1970), Band 7: Vorträge und Aufsätze (pp. 67-98). Frankfurt am Main: Vittorio Klostermann.

Heidegger, M. (2000c). Wer ist Nietzsches Zarathustra? In F. W. Von Herrmann (Ed.), Martin Heidegger Gesamtausgabe. I. Abteilung: Veröffentliche Schriften (1910-1970), Band 7: Vorträge und Aufsätze (pp. 99-126). Frankfurt am Main: Vittorio Klostermann.

Heidegger, M. (2000d). Wissenschaft und Besinnung (1953). In F. W. Von Herrmann (Ed.), Martin Heidegger Gesamtausgabe. I. Abteilung: Veröffentliche Schriften (1910-1970), Band 7: Vorträge und Aufsätze (pp. 37-66). Frankfurt am Main: Vittorio Klostermann.

Hopkins, B. (2003). Crisis, history, and Husserl's phenomenological project of desedimenting the formalization of meaning: Jacob Klein's contribution. Graduate Philosophy Faculty Journal, 24(1), 75-102.

Husserl, E. (1971). Ideen zur einer reinen Phänomenologie und phänomenologischen Philosophie. Drittes Buch: Die Phänomenologie und die Fundamente der Wissenschaften. V. Husserliana, M. Biemel (Eds.). Den Haag: Martinus Nijhoff.

Husserl, E. (1973). Cartesianische Meditationen und Pariser Vorträge. I. Husserliana, S. Strasser (Ed.). The Hague: Martinus Nijhoff.

Husserl, E. (1976a). Ideen zu einer reinen Phänomenlogie und phänomenlogischen Philosophie. Erstes Buch: Allgemeine Einführung in die reine Phänomenologie. Husserliana III/1, K. Schumann (Ed.). The Hague: Martinus Nijhoff.

Husserl, E. (1976b). Krisis der europäischen Wissenschaften und die Transzendentale Phänomenologie: Eine Einleitung in die Phänomenologische Philosophie. Husserliana VI, W. Biemel (Ed.). The Hague: Martinus Nijhoff.

Husserl, E. (1984). Logische Untersuchungen. Band I-II. Husserliana XIX/1-XIX/2, U. Panzer (Ed.). Den Haag: Nijhoff. 
Husserl, E. (1994). Briefwechsel. Band VII: Wissenschaftlercorrespondenz, K. Schumann (Ed.). Dordrecht: Springer.

Husserl, E. (1997a). Experience and Judgment. Evanston: Northwestern University Press.

Husserl, E. (1997b). Psychological and Transcendental Phenomenology and the Confrontation with Heidegger (1927-1931). T. Sheehan, R. E. Palmer (Eds.). Dordrecht: Springer.

Husserl, E. (2001). Natur und Geist: Vorlesungen Sommersemester 1927. Husserliana XXXII. M. Weiler (Ed.). Dordrecht: Kluwer Academic Publishers.

Husserl, E. (2002). Einleitung in die Philosophie: Vorlesungen 1922/23. Husserliana XXXV, R. Bernet, U. Melle (Eds.). Dordrecht: Springer.

Husserl, E. (2003). Transzendentaler Idealismus: Texte aus dem Nachlass (1908-1921). Husserliana XXXVI, R. D. Rollinger (Ed.). Dordrecht: Springer.

Ingarden, R. (1972). What is new in Husserl's 'Crisis'. In A. T. Tymieniecka (Ed.), Analecta Husserliana (Vol. II). Dodrecht: D. Reidel Publishing Co.

Kuhn, T. S. (1962). The structure of scientific revolutions. In O. Neurath (Ed.), International encyclopedia of unified science. Chicago: University of Chicago.

Lovitt, W. (1977). Introduction. In The question concerning technology and other essays (transl. W. Lovitt). New York: Harper Perennial.

Melle, U. (1991). The development of Husserl's ethics. Études Phénoménologiques, 7(13/14), 115-135.

Melle, U. (1998). Responsibility and the crisis of technological civilization: A Husserlian meditation on Hans Jonas. Human Studies, 21(4), 329-345.

Melle, U. (2010). Husserls Beweis für den transzendentalen Idealismus. In C. Ierna, H. Jacobs, \& F. Mattens (Eds.), Philosophy, phenomenology, sciences: Essays in commemoration of Edmund Husserl. Dordrecht: Springer.

Moran, D. (2012). Husserl's Crisis of the European sciences and transcendental phenomenology: An introduction. Cambridge: Cambridge University Press.

Morisson, J. C. (1977). Husserl's 'Crisis': Reflections on the relationship of philosophy and history. Philosophy and Phenomenological Research, 37(3), 312-330.

Nicholson, G. (1985). The ontological difference. American Philosophical Quarterly, 33(4), 357-374.

Pleger, W. H. (1989). Heideggers Kritik der neuzeitlichen Wissenschaft und Technik, Zeitschrift für philosophische Forschung (pp. 641-655), Bd. 43, H. 4.

Wheeler, M. (2011). Martin Heidegger. In N. Zalta (Ed.), Stanford Encyclopedia of Philosophy. https:// plato.stanford.edu/entries/heidegger/. Accessed Mar 2018.

Publisher's Note Springer Nature remains neutral with regard to jurisdictional claims in published maps and institutional affiliations. 